\title{
航空機搭載型疑似衛星による GPS 補完試験について*1 Testing of GPS Augmentation by Aircraft-Based Pseudolite
}

\author{
辻 井 利 昭*2 張 替 正 敏*2 \\ Toshiaki TsujII, Masatoshi Harigae, Kazuki Okano and Hung-Kyu LeE
}

Key Words : GPS, Pseudolite, Helicopter, UAV, Positioning

\begin{abstract}
Pseudolites have potential to enhance the performance of GNSS, and research and developments have been conducted in several aspects. If pseudolites were mounted on aircrafts, its GNSS-like signal would be stable augmentations that would improve the accuracy, availability, and integrity of GNSS-based positioning systems. A pseudolite installed on a stratospheric airship, or a high-altitude unmanned aerial vehicle, could be used as a continuous GNSS augmentation, while a pseudolite on a helicopter could be used as a temporal navigation aid for emergency vehicles in hazardous area. In order to establish fundamental technologies for such a system, the augmentation tests using a GPS pseudolite installed on a helicopter were conducted. The position of the pseudolite antenna underneath the helicopter, which is analogous to the GPS 'precise ephemeris', was successfully determined with a few centimeters accuracy by inverted GPS method. Also, the results demonstrate the efficacy of integrating the pseudolite signal with GPS.
\end{abstract}

1. は じめ に

スードライト (Pseudolite, 疑似衛星) とは GPS 等の測 位衛星システム (GNSS) と同樣の信号を送信する機器で， GNSS 衛星と同樣に使用できるため, 可視衛星数が少ない 場合や, 高度な信頼性が要求される場合に有効と考えられ 研究開発が進められている. 通常は地上に設置され, 例え ば都市部での歩行者ナビゲーション支援を行う場合にはビ ルの屋上から道路に向けて信号を送信する ${ }^{1 \sim 3)}$. また, 空港 で着陸航法支援に使用する場合には空港近辺の地上に設置 して航空機に向けて送信される4).一方，スードライトを飛 行船やへリコプタ等の航空機に搭載すれば, 地上設置型に 比べて遙かに広い範囲でGNSS を補完することができると 考えられる.近年, 地球環境計測，監視等を目的とした高 高度航空機システム (High Altitude Platforms Systems， HAPS ) の研究開発が世界中で活発に行われている.我が国 では平成 10 年度から，成層圏にプラットフォーム (Stratospheric Platform, SPF) を高度 $20 \mathrm{~km}$ に滞在させて, 通 信・放送や地球観測に利用するための研究開発プロジェク 卜が, 文部科学省と総務省を中心として実施され, 平成 16 年度に定点滞空飛行試験が成功裏に終了した ${ }^{5)}$.このSPF にスードライトを搭載すれば, 地上スードライトと比べて 広範囲に GNSS 衛星の補完ができ, 地上, 海上および対流 圏内のユーザに航法測位サービスが提供できると考えられ る ${ }^{6 \sim 10)}$. GNSS 衛星を使用せずに航空機搭載スードライト

\footnotetext{
*1 (C) 2007 日本航空宇宙学会

平成 18 年 8 月 21 日原稿受理

*2 宇宙航空研究開発機構

*3 測位衛星技術(株)

*4 Changwon 国立大学
}

のみによる航法測位システムも構成可能である (第 1 図). また，有人無人の航空機やへリコプタに搭載したスード ライトを使用したシステムも考えられる. 兴の場合 , 対象 領域は狭くなるものの, ダムや橋梁等の大型設備建造支援 や災害など非常時の航法援助手段として利用できる. 災害 時や，山岳での救難援助作業にはへリコプタの使用が有効 であるが, 都市部や山岳地ではへリコプタが単独で運航す るよりも，指揮を行うへリコプタの指示に従い援助作業を 行う方が安全で効率的と考えられる (第 2 図).ここで, 支 援へリは地上の支援車等の情報をもとに有人 · 無人の作業 ヘリに指示や情報を与えるとともに測距信号を発信して測 位システムの信頼性を向上させることができる . 宇宙航空 研究開発機構 (JAXA) では, これら航空機搭載型スードラ イトの有効性を検証するために, 地上基礎試験の他, 実際 にヘリコプタにスードライトを搭載して飛行試験を実施し ており，本稿で試験結果について報告する 。

\section{2. 航空機搭載型スードライトの放送暦生成法}

2.1 スードライト・アンテナの位置推定法 航空機搭載 型スードライトを GNSS の補完に使用するためには , 兴の 放送暦の生成方法が重要な技術課題となる.GNSS では衛 星は軌道運動をしているためユーザは軌道パラメータから 衛星の位置を計算し，パラメータの更新頻度は 1 時間に 1 回程度でよい．しかし，航空機は不規則に運動するため位 置予測は難しく，光れらの位置を高頻度にユーザに提供す る必要がある.リアルタイムサービスのためには, 航空機 の運動と要求精度を考慮して放送軌道暦を更新する必要が ある.最も簡単な方法としては, 航空機の位置を GPSに より推定し，光れを放送暦として送信する方法である．例 えば, DGPS/INS で航空機の位置（GPS アンテナまたは， 


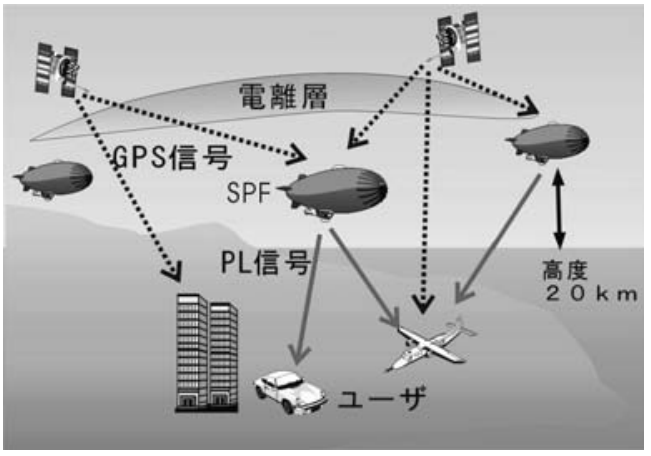

第 1 図＼cjkstart滞留型飛翔体に搭載した疑北衛星による航法測位システム

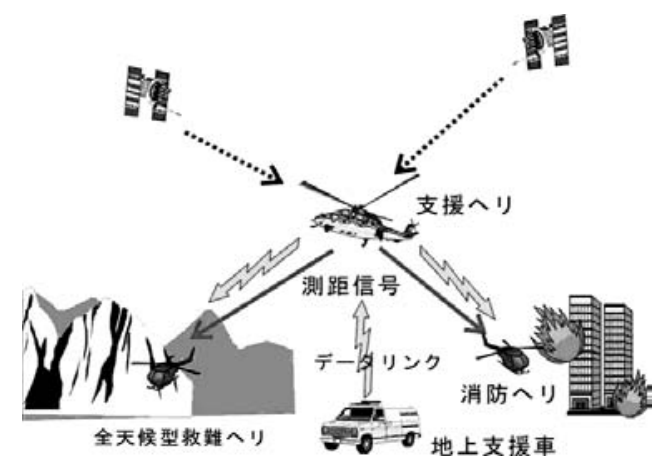

第 2 図＼cjkstart災害時における航法支援システムの概念図

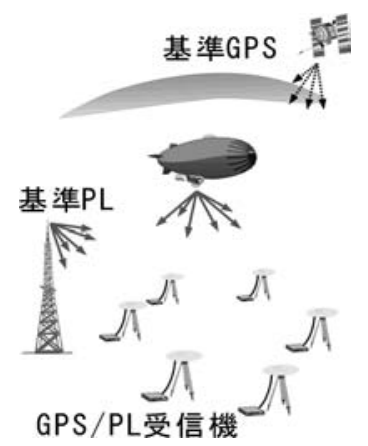

第 3 図逆 GPS 法による軌道暦生成の概念図

INS の位置) を高精度に推定し，姿勢情報を用いてスード ライト・アンテナの位置を計算して放送暦とする方法があ る.また，GPSに頼らず，地上に設置したスードライト受 信機のデータから航空機搭載スードライトの位置を計測す る方法もある. GPS では通常受信アンテナの位置を計算す るのに対し，ここでは送信アンテナの位置を計算するため， この手法を逆 GPS 法 , または逆スードライト法と呼んでい る $^{11)}$. 地上の受信局を用いて飛翔体の位置を計測する手法 は, 人工衛星の場合には軌道決定法として普通に使用され ているが, 航空機の場合には軌道運動をしていないため高 頻度に位置推定を行わなければならない点が異なる．第 3 図に光の概念図を示す. 本手法では, 航空機搭載スードラ イトの他に位置か既知の信号発信源を用いる．発信源とし て GPS 衛星や, 地上設置スードライトが考えられる.地上 スードライト信号は電離層遅延を含まないので GPS より

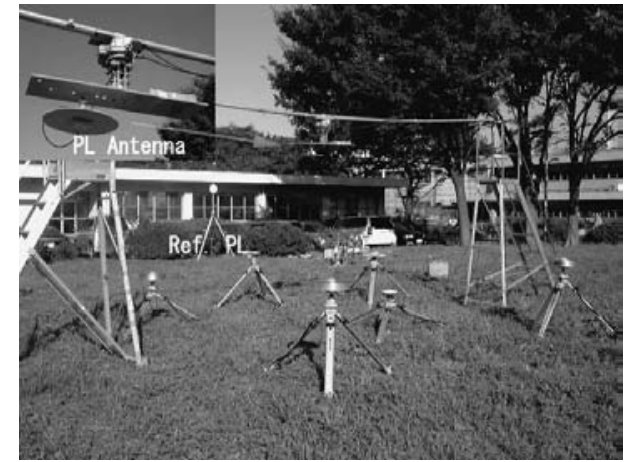

第4図 キネマティック逆 GPS の地上実験システム

も精度面で有利であるが, 地上 GPS/PL 受信機からの見通 しが必要なため, 高い塔の上など設置場所の制限を受ける. ただしこの欠点は, 通常のスードライトの代わりにトラン シーバ型スードライトを使用することで解消できる ${ }^{6,12)}$.

2.2 逆 GPS 地上試験 JAXA では航空機に対する逆 GPS 法の確立を目的として，第 4 図のような地上実験シ ステムを構築し， 2002 年 8 月に測位実験を行った ${ }^{9)}$. 実験 場は四方を建物に囲まれており，マルチパスの多い環境で あるが，高性能アンテナを使うことでマルチパスの軽減を 行った . PL は IntegriNautics 社の IN400を移動側と地上 基準として使用した . 移動側 PL アンテナは第 4 図の左上 に示すようにモータで回転させることができる．また，木 製のアンテナにはアンテナ取り付け用の穴が複数あり，回 転半径を変更することができる. 受信機は古野電気社製の GPS/PL 受信機 PL-10を 6 台地上に配置し,チョークリン グ・アンテナ 3 個 , Ashtech Geodetic IV アンテナ (グラン ドプレーン付き） 3 個と接続した . 観測データ $(5 \mathrm{~Hz})$ は， LAN に接続した 2 台のラップトップ PCで記録した . 記録 したデータはJAXA で開発したキネマティック GPS ソフ トウエア, KINGS を改修して処理した ${ }^{13)}$.式(1) は, 本ソ フトウェアで使用する搬送波二重差の観測方程式である .

$$
\begin{aligned}
\nabla \Delta \Phi_{\mathrm{ab}}^{1 i}= & \left|\boldsymbol{X}^{1}-\boldsymbol{X}_{\mathrm{a}}(t)\right|-\left|\boldsymbol{X}^{i}-\boldsymbol{X}_{\mathrm{a}}(t)\right| \\
& -\left|\boldsymbol{X}^{1}-\boldsymbol{X}_{\mathrm{b}}\left(t_{\mathrm{b}}\right)\right|+\left|\boldsymbol{X}^{i}-\boldsymbol{X}_{\mathrm{b}}\left(t_{\mathrm{b}}\right)\right| \\
& +\nabla \Delta N_{\mathrm{ab}}^{1 i}+\nabla \Delta d_{\text {multi }}+\nabla \Delta \varepsilon \\
(i=2,3, & \cdots, n)
\end{aligned}
$$

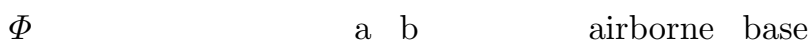
スードライトを示し，本実験ではａは回転するスードライ 卜 , b は地上の基準スードライトである . 上付の添字 $1, i$ は

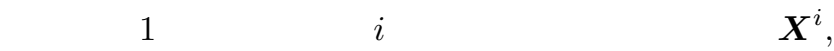
$\boldsymbol{X}_{\mathrm{a}}, \boldsymbol{X}_{\mathrm{b}}$ は, 乥れ艺れ $i$ 番目の受信機アンテナ, 回転スード ライト・アンテナ, 基準スードライト・アンテナの位置ベク トルである . 時刻 $t, t_{\mathrm{b}}$ は回転スードライト, 基準スードラ イトから各受信機に信号を送信した時刻である. $N, d_{\text {multi }}$,

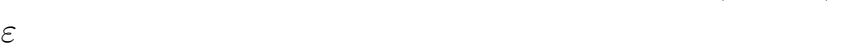
観測ノイズを示す．電離層より低い場所に設置されたスー ドライトのデータには，GPS データに含まれる電離層遅延 誤差は存在しない，また，対流圈遅延量は本試験のような 


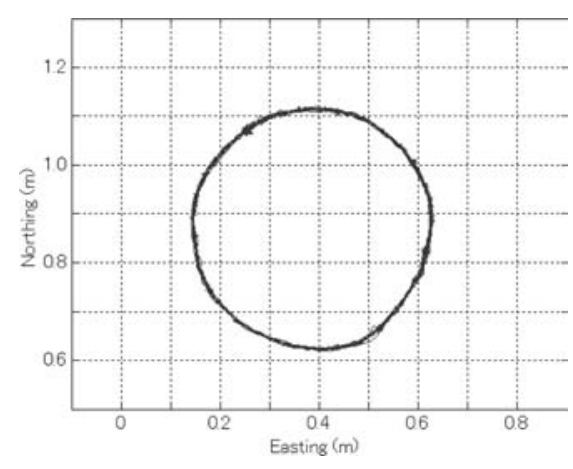

第 5 図 キネマティック逆 GPS で推定した移動 PL 軌道 (半径 $24 \mathrm{~cm}$ )

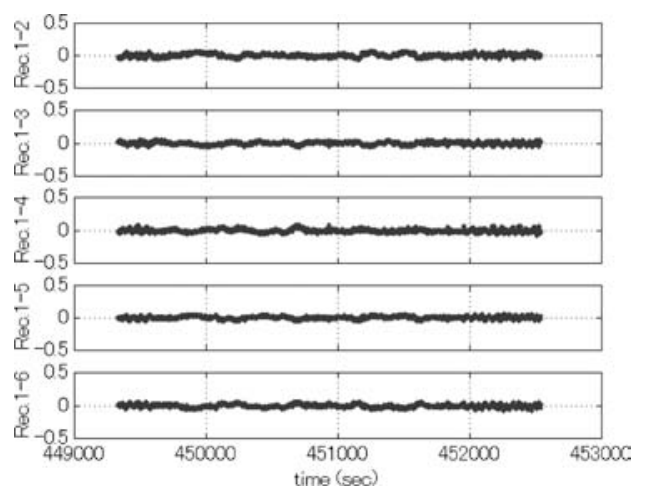

第 6 図 二重差観測残差 (単位 : cycles)

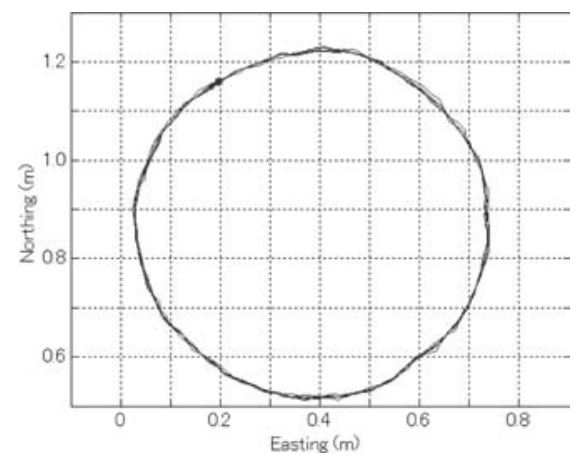

第 7 図 キネマティツク逆 GPS で推定した移動 PL 軌道 (半径 $35 \mathrm{~cm}$ )

ごく狭い領域での試験では無視できる．本試験では 6 台の 受信機を使用しているので二重差の式 $5 つ よ り ，$ 回転スー ドライト・アンテナの位置座標を推定する . アンビギュイ ティは通常の探索法により決定し，位置推定の前に式 (1) より除くことが必要となる．

第 5 図は, 逆 GPS 法で推定した移動 PL の軌道の例であ る.これは 11 回転した PL アンテナの軌道の重ね合わせで ある (半径 $24 \mathrm{~cm}$ ). 軌道推定の際の観測残差を第 6 図に示 す . 各二重差の残差は $0.020 \sim 0.027$ cycles $(3.8 \sim 5.1 \mathrm{~mm})$ であった . 第 7 図は半径を $35 \mathrm{~cm}$ とした場合の軌跡である. 本試験では，精度評価の基準となる移動 PL 位置の計測を 行わなかったので, 真の位置精度評価はできなかったが, 推 定した回転半径と既知の半径の值を比較した (第 1 表). 標 準偏差は $5 \mathrm{~mm}$ 以下であり，アンビギュイティは正しく決
第 1 表 推定した回転半径の標準偏差 (Case 2, 3 は关れ

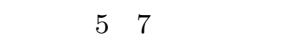

\begin{tabular}{cccc}
\hline Case & $\begin{array}{c}\text { Radius } \\
(\mathrm{cm})\end{array}$ & $\begin{array}{c}\text { Number of } \\
\text { data }\end{array}$ & $\begin{array}{c}\text { Standard deviation } \\
(\mathrm{cm})\end{array}$ \\
\hline 1 & 24 & 763 & 0.52 \\
2 & 24 & 3217 & 0.48 \\
3 & 35 & 1159 & 0.46 \\
4 & 19 & 1472 & 0.41 \\
\hline
\end{tabular}

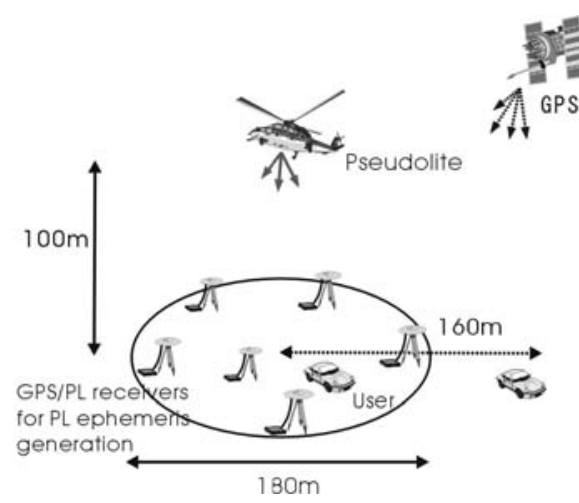

第 8 図 GPS/PL システム飛行実験概念図

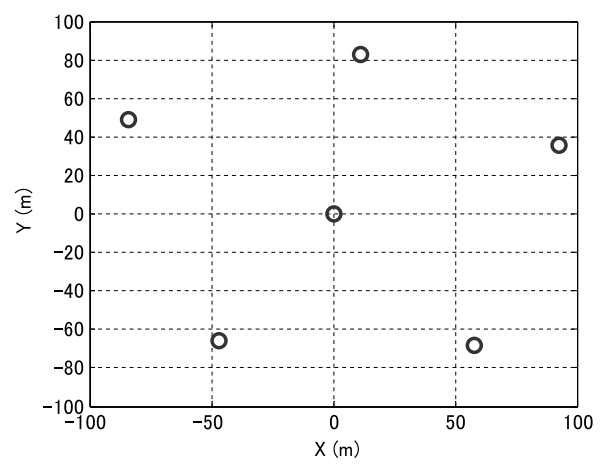

第 9 図 GPS/PL 受信アンテナの配置 (水平方向)

定されたと推定できる . 若干円の形がいびつな部分がある が , これは高性能 GPS アンテナでも除去できなかったマ ルチパス誤差が原因と考えられる .

\section{3. ヘリコプタによる GPS 補完試験}

3.1 飛行試験の概要 地上試験により，逆 GPS 法の基 本的技術か確立できたので，次に滞留型飛翔体としてへリ コプタを用いて GPS/PL システムの飛行試験を行った . 本 試験の目的は，飛翔体の精密軌道暦が作成できることを実 証することと，飛翔体からのスードライト信号が測位に使 用可能なことを実証することである．

第 8 図に実験概念図を示す.地上の半径約 $90 \mathrm{~m}$ の領域に 設置された GPS/PL 受信機 (Furuno PL-10) 6 台は, 精 密軌道暦作成用である . 各受信機にはマルチパス軽減のた めAshtech 社製チョークリングアンテナを接続した .アン テナの配置图を第 9 図に示す .スードライトは Spirent 社製 GSS4100p を用いた . 㚇の諸元を第 2 表に示す.第 10 図は ヘリコプタ下部に設置したアンテナである.第 11 図はロー 


\begin{tabular}{ll}
\multicolumn{1}{c}{ 第2 表 } & スードライトの主要諸元 \\
\hline \multicolumn{1}{c}{ 項目 } & \multicolumn{1}{c}{ 仕樣 } \\
\hline 周波数 & L1 $(1575.42 \mathrm{MHz})$ \\
PRN コード & PRN 1-37 (GPS) \\
& PRN 1-37 (RTCM SC-104) \\
& PRN 120-138 (SBAS) \\
チップレート & $1.023 \mathrm{MHz}$ \\
送信モード & 連続, およびパルス \\
変調方式 & BPSK \\
送信信号レベル & $-130 \mathrm{dBm},-70 \mathrm{dBm}$ \\
データレート & $50 \mathrm{bps}(\mathrm{GPS}), 250 \mathrm{bps}(\mathrm{SBAS})$ \\
形状 & $99 \times 254 \times 345(\mathrm{~mm})$ \\
重量 & $5 \mathrm{~kg}$ \\
\hline
\end{tabular}

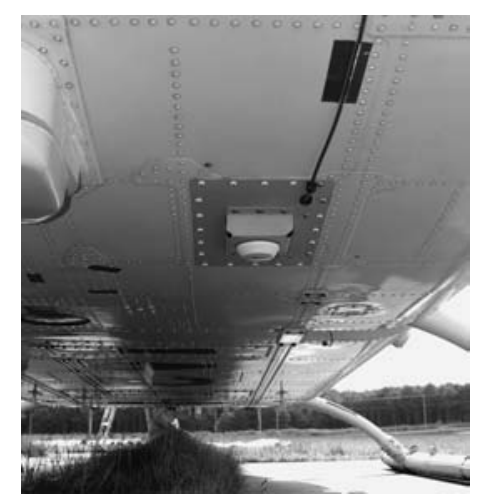

第10図 スードライト・アンテナ

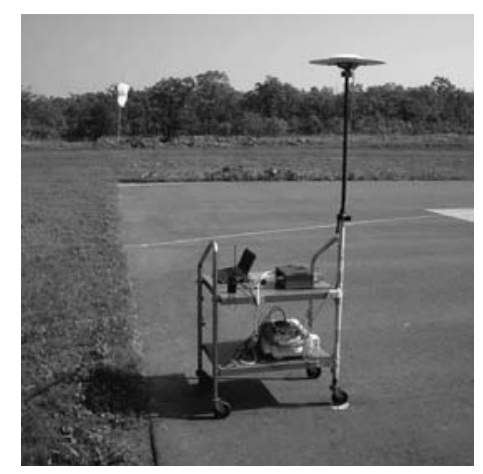

第11図 ローバ受信機

バの写真で, 受信機 (Furuno PL-10) , アンテナ (Ashtech 社製 Geodetic IV)，データ収集用 PC，バッテリを搭載し ている。

飛行試験は平成 15 年 6 月 23 日に北海道大樹町の多目的 航空公園で実施した .試験におけるへリコプタの軌跡を第 12 図に示す . 半径約 $15 \mathrm{~m}$ の領域に滞空した . 高度は $70 \mathrm{~m}$ から $100 \mathrm{~m}$ であった (第 13 図).

3.2 逆 GPS 法によるスードライト・アンテナの位置推 定地上試験と同樣に, PC に収録したデータを後処理し てヘリコプタに搭載したスードライト・アンテナの位置を 逆 GPS 法によって決定した .この時，搬送波二重差の観 測方程式は (2) 式で表される .

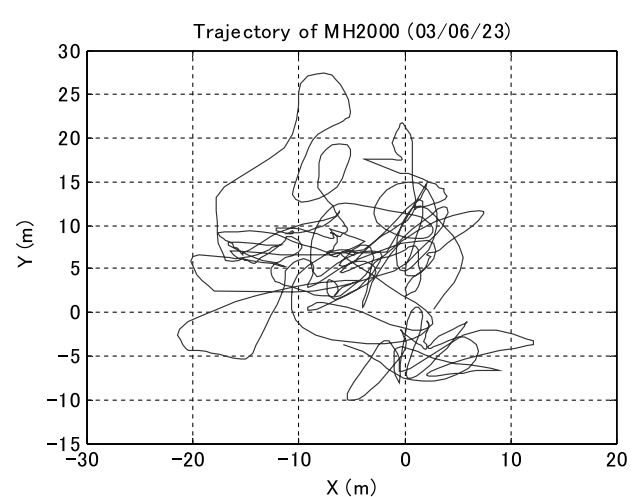

第 12 図 ヘリコプタの軌跡 (水平面図)

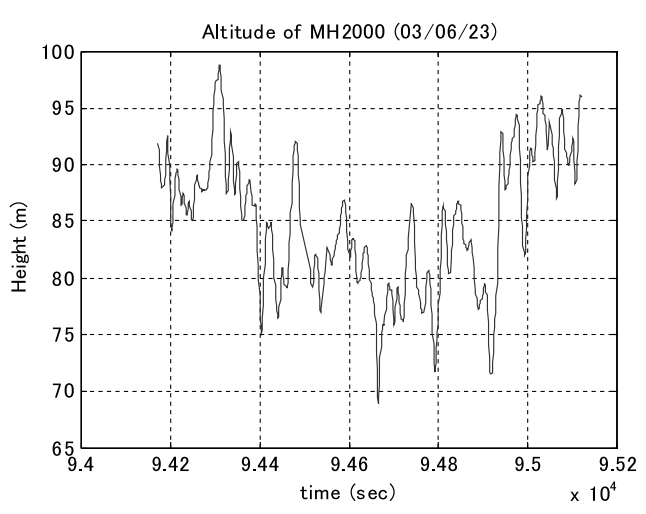

第 13 図高度履歴

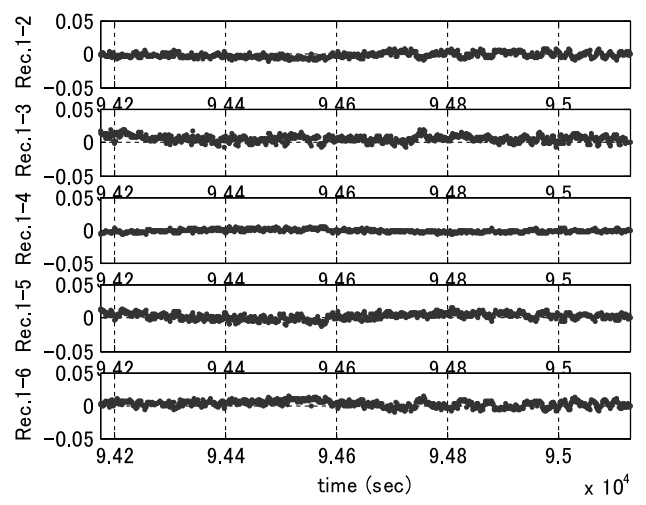

第 14 図 逆 GPS 法における L1 搬送波の二重差観測残差 (単位 : m)

$$
\begin{aligned}
& \nabla \Delta \Phi_{\mathrm{ab}}^{1 i}=\left|\boldsymbol{X}^{1}-\boldsymbol{X}_{\mathrm{a}}(t)\right|-\left|\boldsymbol{X}^{i}-\boldsymbol{X}_{\mathrm{a}}(t)\right| \\
&-\left|\boldsymbol{X}^{1}-\boldsymbol{X}_{\mathrm{b}}\left(t_{\mathrm{b}}\right)\right|+\left|\boldsymbol{X}^{i}-\boldsymbol{X}_{\mathrm{b}}\left(t_{\mathrm{b}}\right)\right| \\
&+\nabla \Delta N_{\mathrm{ab}}^{1 i}+\nabla \Delta d_{\text {multi }}+\nabla \Delta d_{\text {trop }}+\nabla \Delta \varepsilon \\
&(i=2,3, \ldots, n)
\end{aligned}
$$

地上試験では，基準送信機として地上スードライトを 使用したが, 本飛行試験では, 最も高度の高い GPS 衛星 (PRN24) を基準送信機としたので，下付の b は基準 GPS 衛星を示す.また, (1) 式と異なり対流圏遅延の項 $d_{\mathrm{trop}}$ が 加わっている. 対流圈遅延量はモデル計算するが , 飛行試 験の場合，高度が $100 \mathrm{~m}$ 程度でも，モデル誤差が二重差に 


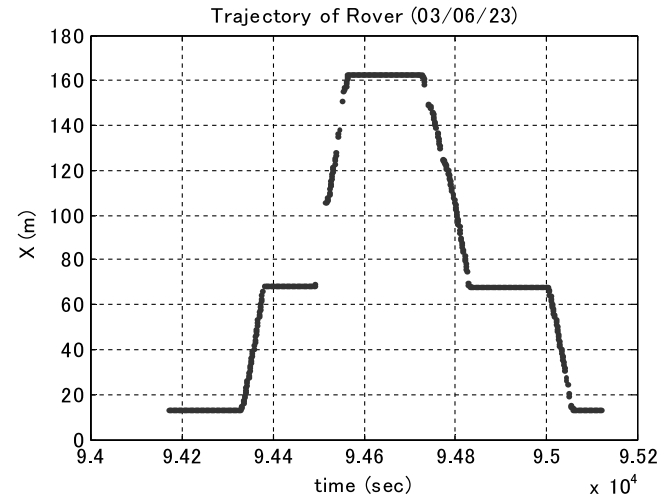

第 15 図 ローバ (ユーザ受信機) の軌道

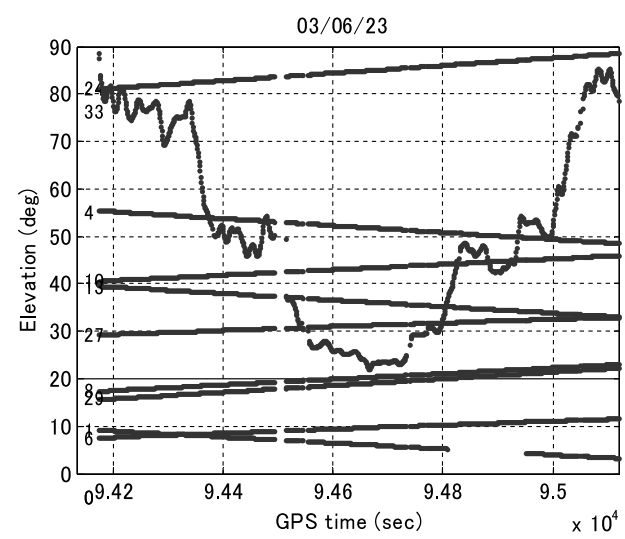

第16図 ローバから見た PL および GPS 衛星の仰角

おいて数 $\mathrm{cm}$ に達することがあるためである .

ヘリコプタの位置を逆 GPS によって決定した際の L1 搬 送波の二重差観測残差を第 14 図に示す.上から受信機 1 と， 受信機 $2,3,4,5,6$ の組み合わせに対応している.軌道精 度評価のためのリファレンス軌道はないが , 残差の RMS は 2.2 7.0 mm で, DOP が約 3 であったので測位誤差は 約 $6 \mathrm{~cm}(3 \sigma)$ と考えられ，精密軌道決定が澾成できたとい える。

3.3 GPS 補完試験 次に飛翔体からの PL 信号を地上 ユーザが使用可能か評価するためにローバの測位試験を行っ た。ローバは, 軌道決定用受信機の中心付近を出発し, 滑 走路方向に約 $60 \mathrm{~m}$ 移動して静止，弚の後さらに約 $90 \mathrm{~m}$ 移 動して静止したのち出発点に戻った (第 15 図).この時， ローバから見た GPS 衛星とヘリコプタの仰角を第 16 図に 示す. GPS 衛星の仰角の変化は緩やかだが, ヘリコプタの 仰角は高度が低いためローバの移動とともに大きく変化す ることがわかる . 図中にデータの欠落が見られるが，これ はローバ受信機と記録用 PC 間の通信障害によるもので， サイクルスリップは生じていなかった .

次に, GPS 単独および，GPS/PL 単独測位試験の結果 を示す．ここで，単独とは，地上局の補正量を使用しない こと，すなわちディファレンシャル測位ではないことを意 味する . GPS 信号の電離層遅延量は, Klobuchar ${ }^{14)}$ のモデ ルにより計算した ・また，GPS およびPL 信号の対流圏遅

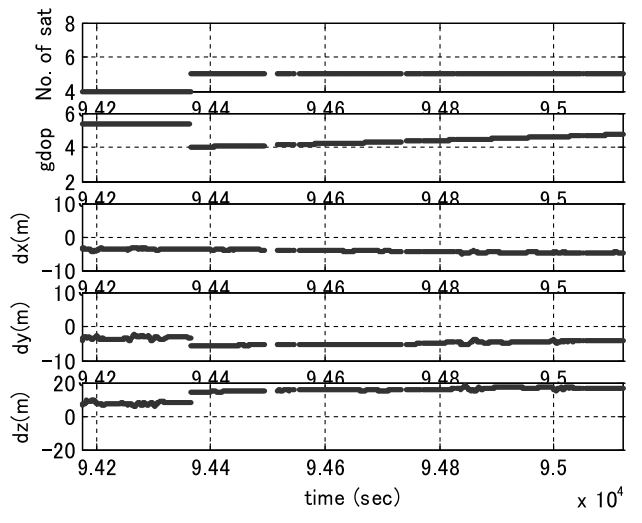

第 17 図 GPS 単独測位における衛星数, GDOP, 測位誤差 (マスク 角 30 度)

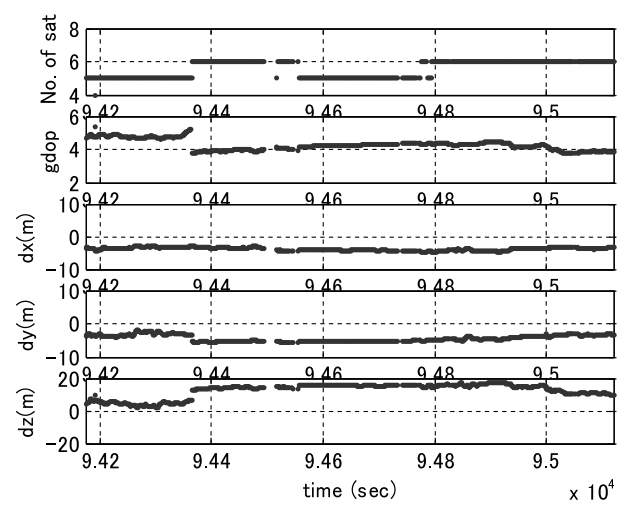

第 18 図 GPS/PL 単独測位における衛星数, GDOP, 測位誤差 (マ スク角 30 度)

延量は Zaastanoinen ${ }^{15)}$ のモデルに従って計算した . PL の クロックバイアス (距離に換算) は，地上基準局における $\mathrm{PL}$ の疑似距離観測データ $\left(P R_{\mathrm{base}}^{\mathrm{PL}}\right)$ を使って式 (3) によ り計算した .ここで, $\rho_{\mathrm{base}}^{\mathrm{PL}}$ は基準局と PL アンテナの距離 で, 逆 GPS 法によって精密に求めた PL アンテナの位置と, 既知の基準局位置を用いて計算した．また， $b_{\text {base }}$ は基準 局で使用した GPS/PL 受信機の時計誤差で, GPS 単独測 位により別途計算した . $b_{\text {trop }}$ は対流圏遅延量である.この ようにして計算した PL の時計誤差には数 $\mathrm{m}$ の誤差がある と考えられる. 疑似距離単独測位で推定した $b_{\text {base }}$ の誤差, および疑似距離の観測ノイズがあるからである．PL 時計 誤差のより精密な推定方法としては, 単独精密測位による $b_{\text {base }}$ の高精度推定，フィルタリングによるノイズの低減等 考えられるが , 今後の課題とする . 本手法による GPS/PL 単独測位では，地上局データを使用しているので厳密には 単独測位ではないが, 将来的には GPS 放送暦の GPS 衛星 時計誤差パラメータのように，推定した PL の時計誤差を ユーザに放送することを想定している .

$$
b^{\mathrm{PL}}=-\left(P R_{\text {base }}^{\mathrm{PL}}-\rho_{\text {base }}^{\mathrm{PL}}-b_{\text {base }}-b_{\text {trop }}\right)
$$

測位結果を GPS と GPS/PL の場合で比較したが，マス ク角 10 度とした場合，両者の差はほとんどなかった . 、 スク角 10 度では, 衛星数は十分であり, PL 1 台の追加に 
第3 表 GPS および GPS/PL 単独測位精度

\begin{tabular}{cccccc}
\hline RMS & \multicolumn{2}{c}{ Mask $=10$ degrees } & & \multicolumn{2}{c}{ Mask $=30$ degrees } \\
\cline { 2 - 3 } \cline { 5 - 6 } error $(\mathrm{m})$ & GPS & GPS $/$ PL & & GPS & GPS $/$ PL \\
\hline$X$ & 3.5 & 3.3 & & 4.2 & 3.8 \\
$Y$ & 2.8 & 2.8 & & 4.7 & 4.5 \\
$Z$ & 5.0 & 4.7 & & 14.5 & 13.1 \\
\hline
\end{tabular}

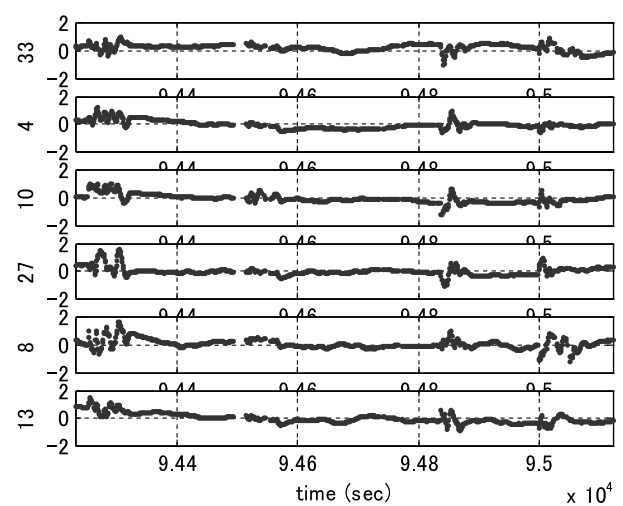

第 19 図 L1 疑似距離の二重差観測残差 (単位 : m)

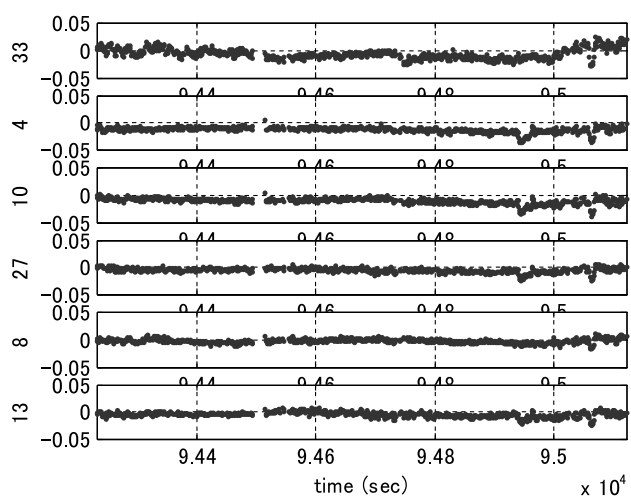

第 20 図 L1 搬送波の二重差観測残差 (単位 : m)

よって GDOP がほとんど変わらなかったためと考えられ る.次にマスク角を 30 度として測位計算を行った . GPS

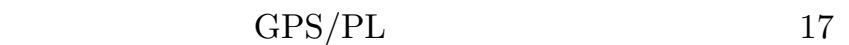
18 図に示す.上から，㚇れ光れの場合における観測衛星数 (PL 含む)，GDOP，測位誤差である。測位誤差は GPS の み使用したキネマティック測位結果を基準として計算した $X$ が滑走路方向， $Y$ が横方向， $Z$ が上方向である.衛星数 を見ると，GPS タイムが 94550〜94800 (sec) 近辺以外で は, PL 1 機分増加していることがわかる.この時間帯は第 16 图より PL の仰角も 30 度未満となっていて測位に使用 されていない，光れ以外の時間帯では, 衛星数の増加によ り若干の測位精度の向上が見られる. 第 3 表に GPS およ び GPS/PL 単独測位精度をまとめる.

次に，GPSおよびGPS/PL 相対測位計算を行った .こ こでは, 最も高高度の GPS 衛星 (PRN24) を基準の送信機 として観測量の二重差を構成し，測位計算を行った。第 19 図は L1 疑似距離の二重差観測残差で, 上から順に PRN33 (PL) , PRN4，10，27，8，13 に対応している.PL に対す

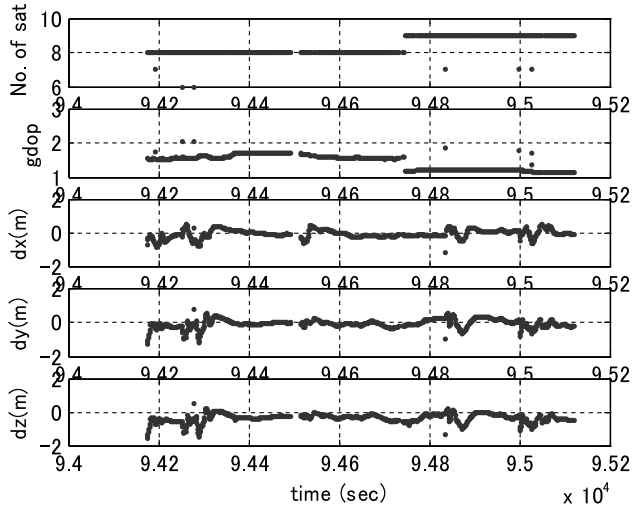

第 21 図 DGPS と DGPS/PL 測位の比較

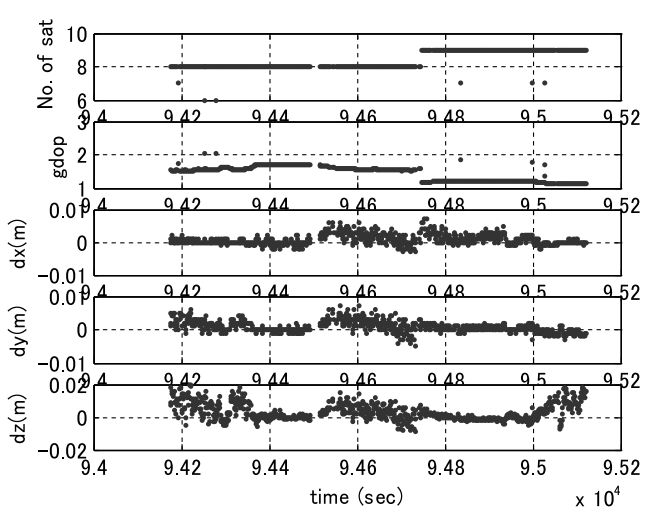

第22図 KGPS と KGPS/PL 測位の比較

る残差の RMS は $32 \mathrm{~cm}$ で, GPS の光れとほぼ同じであっ た $(30 \sim 37 \mathrm{~cm})$. 一方，第 20 图は L1 搬送波の二重差観測 残差である. 兴の RMS は PL で $1.1 \mathrm{~cm}$, GPS で $0.5 \sim$ $1.4 \mathrm{~cm}$ であった . これらの結果より，PL 信号の観測ノイ ズは，GPS の弚れとほぼ同じであることがわかった .

これらの観測量を使い，GPS 相対測位と GPS/PL 相対 測位の比較を行った . ママスク角は 10 度とした . 第 21 図は 疑似距離相対測位 (ディファレンシャル測位) の比較結果で ある.上から 1,2 番目の図は弚れ光れ PL を含んだ時の衛 星数, 相対 GDOP で, 弚れ以下は測位結果の差で, $X, Y$,

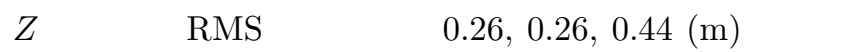
た。第 22 図は搬送波相対測位 (キネマティック測位) の差 を示す . $X, Y, Z$ 各軸での RMS は 1.7, 1.8, $6.0(\mathrm{~mm})$ で あった . 疑似距離および搬送波の観測ノイズの大きさを考 慮すると，GPS と GPS/PL 相対測位結果はほぼ同じと考 えられ，本実験では PL を追加しても測位精度の改善はな かったという結果となった .これは，本試験のように基線 長 (基準局とユーザ局の距離) が短い場合には対流圈遅延 等の系統誤差が二重差によりほぼ完全に相殺するためであ る・ただし，PL 信号が GPS 信号と同樣に使用できること は実証されたと考えられる．また，PLの追加によって測位 精度が劣化しなかったことは, 逆 GPS 法によって PL アン テナ位置が高精度に推定できたことの傍証となっている． 


$$
\text { 4. おわり に }
$$

本論文では, 航空機搭載型スードライトの有効性と実現 可能性を地上および飛行試験により示した . 人工衛星や地 上設置型スードライトと異なり, 航空機搭載型ではその送 信アンテナ位置 (GNSS の軌道暦に相当) の推定法が課題 となる . はじめに, 逆 GPS 法の地上試験によりスードライ トのアンテナ位置をセンチメートル・レベルで推定できる ことを示し, 次にへリコプタに搭載したスードライト・ア ンテナ位置を同等の精度で推定できることを示した .さら に，航空機搭載型スードライトによって，GPS を補完し， GPS/PL 単独測位, 疑似距离隹相対測位, 搬送波相対測位が 可能なことを示した .

航空機搭載型スードライトは地上設置型に比べて広覆域 という利点があり，GPS の補完として精度・利用性・信頼 性の向上に有効と考えられる . 成層圏プラットフォームや 高高度無人機等に搭載した連続的補完システムとして, ま たヘリコプタ搭載の災害等非常時における航法援助システ ムとしての利用が期待できる .

本研究を進めるにあたり, 豪州ニューサウスウェールズ 大学の Chris Rizos 教授をはじめとする SNAP (Satellite Navigation and Positioning) Group の諸氏から樣々な知 見を頂いた．ここに感謝の意を表する．

\section{参 考 文 献}

1) Altmayer, C.: Experiences Using Pseudolites to Augment GNSS in Urban Environment, 11th Int. Tech. Meeting of the Satellite Division of the U.S. Inst. of Navigation, Nashville, Tennessee, 1998, pp. 981-991.

2) Lee, H. K., Wang, J., Rizos, C. and Tsujii, T.: Augmenting GPS by Ground-Based Pseudolite Signals for Airborne Surveying Applications, Survey Review, 38 (2005), pp. 88-99.

3) Wang, J., Tsujii, T., Rizos, C., Dai, L. and Moore, M.: Integrating GPS and Pseudolite Signals for Position and Attitude Determination: Theoretical Analysis and Experiment Results, 13th Int. Tech. Meeting of the Satellite Division of the U.S. Inst. of Navigation, Salt Lake City, Utah, 2000, pp. $2252-2262$.
4) Barltrop, K., Stafford, J. and Elrod, B.: Local DGPS with Pseudolite Augmentation and Implementation Considerations for LAAS, 9th Int. Tech. Meeting of the Satellite Division of the U.S. Inst. of Navigation, Kansas City, Missouri, 1996, pp. 449-459.

5) 竹田繁一：成層圏プラットフォームプロジェクト, 第 43 回飛行 機シンポジウム講演集, 名古屋 , 2005, pp. 220-226.

6) 辻井利昭, Rizos, C., Wang, J., Dai, L., 張替正敏 : 成層圏プ ラットフォームを用いた疑似 GPS 衛星による航法測位サービス について，日本航空宇宙学会論文集，50 (2002), pp. 36-39.

7) 辻井利昭, 張替正敏, 原田正志: 高高度飛翔体による航法測位シ ステム，航空宇宙学会論文集，52 (2004), pp. 175-185.

8) 辻井利昭, 張替正敏 : 成層圏プラットフォームを用いた疑似 GPS 衛星による航法測位システムについて, 日本航空宇宙学会第 40 回飛行機シンポジウム, $2 \mathrm{E} 3,2002$.

9) Tsujii, T., Harigae, M., Barnes, J., Wang, J. and Rizos, C.: Experiments of Inverted Pseudolite Positioning for AirshipBased GPS Augmentation System, 15th Int. Tech. Meeting of the Satellite Division of the U.S. Inst. of Navigation, Portland, Oregon, 2002, pp. 1689-1695.

10) Dovis, F., Mulassano, P. and Dumville, M.: The Stratolite Concept: Design of a Stratospheric Pseudo-Satellite for Galileo, 15th Int. Tech. Meeting of the Satellite Division of the U.S. Inst. of Navigation, Portland, Oregon, 2002, pp. 347-356.

11) Raquet, J., Lachapelle, G., Qui, W., Pelletier, C., Nash, A., Fenton, P. and Holden, T.: Development and Testing of a Mobile Pseudolite Concept for Precise Positioning, 8th Int. Tech. Meeting of the Satellite Division of the U.S. Inst. of Navigation, Palm Springs, California, 1995, pp. 817-825.

12) Barnes, J., Rizos, C., Wang, J., Small, D., Voigt, G. and Gambale, N.: Locata: A New Positioning Technology for High Precision Indoor and Outdoor Positioning, 16th Int. Tech. Meeting of the Satellite Division of the U.S. Inst. of Navigation, Portland, Oregon, 2003.

13) Tsujii, T., Murata, M., Harigae, M., Ono, T. and Inagaki, T.: Development of Kinematic GPS Software, KINGS, and Flight Test Evaluation, Technical Report of National Aerospace Laboratory, Japan, TR-1357T, 1998.

14) Klobuchar, J. A.: Ionospheric Effects on GPS, Parkinson, B. W. and Spilker, J. J., Jr. (eds), Global Positioning System: Theory and Application, Progress in Astronautics and Aeronautics, 164, American Institute of Aeronautics and Astronautics, Washington, D.C., 1996, pp. 485-515.

15) Saastamoinen, J.: Atmospheric Correction for the Troposphere and Stratosphere in Ranging of Sattelites, Henriksen, S. W., et al. (eds), The Use of Artificial Satellites for Geodesy, Geophys. Monogr. Ser., 15, American Geophysical Union, Washington, D.C., 1972, pp. 247-251. 